\title{
Strengthening the English language reading comprehension by using inferring meaning strategy
}

\section{Fortalecimiento de la comprensión lectora del idioma inglés \\ mediante el uso de la estrategia de inferir significado}

1 Priscila Fernanda Pillaga

https://orcid.org/0000-0001-6316-9477

Universidad Técnica de Ambato, Facultad de Ciencias Humanas y de la Educación, Carrera de Pedagogía de los Idiomas Nacionales y Extranjeros Ambato, Ecuador ppillaga2845@uta.edu.ec

2 Dorys Maribel Cumbe Coraizaca

https://orcid.org/0000-003-1818-5974 Universidad Técnica de Ambato, Facultad de Ciencias Humanas y de la Educación, Carrera de Pedagogía de los Idiomas Nacionales y Extranjeros. Ambato, Ecuador, dm.cumbe@uta.edu.ec

3 Ximena Alexandra Calero Sánchez (iD) https://orcid.org/0000-0003-0763-0892 Universidad Técnica de Ambato, Facultad de Ciencias Humanas y de la Educación. Carrera de Pedagogía de los Idiomas Nacionales y Extranjeros. Ambato, Ecuador. xcalero@uta.edu.ec

$4 \quad$ Ana Jazmina Vera de la Torre https://orcid.org/0000-0003-4698-6242. Universidad Técnica de Ambato, Facultad de Ciencias Humanas y de la Educación. Carrera de Pedagogía de los Idiomas Nacionales y Extranjeros Ambato, Ecuador. aj@uta.edu.ec

Artículo de Investigación Científica y Tecnológica Enviado: $17 / 12 / 2021$

Revisado: 29/12/2021

Aceptado: $12 / 01 / 2022$

Publicado:08/03/2023

DOI: https://doi.org/10.33262/concienciadigital.v6i1.4.1985

Cítese: $\quad$ Fernanda Pillaga, P., Cumbe Coraizaca, D. M., Calero Sánchez, X. A., \& Vera de la Torre, A. J. (2023). Strengthening the English language reading comprehension by using inferring meaning strategy . ConcienciaDigital, 6(1.4), 50-59.

https://doi.org/10.33262/concienciadigital.v6i1.4.1985

CONCIENCIA DIGITAL, es una Revista Multidisciplinar, Trimestral, que se publicará en soporte electrónico tiene como misión contribuir a la formación de profesionales competentes con visión humanística y crítica que sean capaces de exponer sus resultados investigativos y científicos en la misma medida que se promueva mediante su intervención cambios positivos en la sociedad. https://concienciadigital.org

La revista es editada por la Editorial Ciencia Digital (Editorial de prestigio registrada en la Cámara Ecuatoriana de Libro con No de Afiliación 663) www.celibro.org.ec 


\section{Palabras}

claves:

estrategia,

habilidad

lectora, comprensión, inferir, mejora
Keywords:

strategy, reading skill, comprehension, inferring, improvement.

\section{Resumen}

Introducción. El idioma inglés es considerado uno de los idiomas más hablados en todo el mundo. Docentes del idioma inglés debe afrontar el reto de lograr un aprendizaje significativo y para conseguirlo es esencial utilizar algunas estrategias que faciliten el proceso de aprendizaje. A la hora de enseñar una de las cuatro habilidades lingüísticas como es la lectura, hay una gran cantidad de estrategias a aplicar en función del objetivo del lector. Uno de los más útiles es la estrategia de inferir el significado. Objetivo. El objetivo de esta investigación es analizar la eficacia de esta estrategia en el desarrollo de la comprensión lectora en 28 estudiantes del $5^{\circ}$ semestre de PINE (Pedagogía de los Idiomas Nacionales y Extranjeros) de la Universidad Técnica de Ambato. Metodología. En un principio fue necesario aplicar una prueba de diagnóstico para comprobar los conocimientos previos de los estudiantes. Para ello se utilizó la segunda y cuarta parte de la sección de lectura del Preliminary English Test (PET). Los estudiantes tuvieron la oportunidad de practicar la estrategia durante un mes. Durante este período de tiempo, tuvieron que completar algunas actividades de comprensión relacionadas con los textos leídos. Finalmente, el grupo experimental realizó una evaluación de PET para evaluar la efectividad de la estrategia. Resultados. Los resultados obtenidos se analizaron mediante la prueba $\mathrm{T}$ de student a través de la cual se evidenció que la Estrategia de Inferir Significado contribuye al desarrollo y mejoramiento de la comprensión lectora.

\section{Abstract}

Introduction. The English language has become one of the most spoken languages all around the world. English teachers must face the challenge of achieving significant learning and for doing so, it is essential to use some strategies that facilitate the learning process. When teaching reading, which is one of the four language skills, there is a great number of strategies to apply depending on the aim of the reader. One of the most useful is Inferring Meaning Strategy. Objective. The aim of this research is to analyze the efficacy of this strategy when developing reading comprehension in 28 students from the 5th semester of Pedagogy de los Idiom's nationals y estrangers (PINE) at Universidad Técnica de Ambato. Methodology. At first it was necessary to apply a diagnostic test to 
check students' previous knowledge. For this, the second and fourth part from the reading section of the Preliminary English Test (PET) were used. Students had the opportunity of practicing the strategy for a month. During this period, they had to complete some comprehension activities related to readings. Finally, the experimental group took a post- test from PET to evaluate the effectiveness of the strategy. Results. The results obtained were analyzed using the student's t-test. Conclusion. They evidenced that the Inferring Meaning Strategy contributes to the development and improvement of the reading comprehension

\section{Introduction}

Rose (2021) defines inference as the links or connections that exist between the evidence and facts found in the passage and the reader's knowledge about the world. These connections must be meaningful to build a coherent representation and to achieve a better understanding about what is implicitly being transmitted in the text. The ability of making inferences performs an essential part while reading because it enhances coherence within the text and highlights what is expressly specified in the passage (Scholander et al., 2021).

The authors usually write expecting the reader to figure out what is being communicated by paying attention to some specific clues and indications. To do so, the reader needs to activate his memory and his knowledge. To get fully understanding it is necessary to go beyond what is written and build up a consistent mental representation of the situation.

There is also research carried out by Demetriou et al. (2021) named "The impact of reading at rapid rates on inference generation", which was focused on studying how the process of inferring while reading was affected by speed reading and what impact has it in reading comprehension (Anjarwati et al., 2021).

Passages offered readers the opportunity of making inferences about the information presented and about some lexical items (strong, weak, and neutral words) (Johannessen et al., 2021). The conclusions of this research determined that there was not enough evidence that support the fact that right inferences are made when applying speed reading. Yet, the comprehension process by inferring is affected by speed reading (Odii et al., 2021). 


\section{Predictive Inferences}

Omland (2021) suggest that if teachers enhance readers to make predictive inferences, they will eventually turn into interactive readers and will be easier for them to process information and construct mental representations. Under certain circumstances, the probability of inference generation should improve as show figure 1 . They are also known as forward inferences. When doing this type of predictions, the reader focuses mainly on what is more likely to happen because of the situation set in the text (Herazo, 2021).

\section{Figure 1}

\section{Predictive inferences}


The inference strategy has demonstrated to have a good impact when applied to improve reading comprehension. There was a study carried out by Chen (2021), in which they form ed a group of children that were from 6 to 8 years old. There were skilled and less skilled readers, however they all had the same general comprehension abilities. In this study they could conclude that qualified readers generate more inferences and in an easier way than less qualified readers.

Moreover, it was found the article written by Cowley (2021) called "Generating Predictive Inferences When Multiple Alternatives Are Available", the current research has studied how inferences are made when the story has two likely consequences. A contrasting paradigm was used for the second experiment. However, when the contradiction was directed the word to two inferences or deductions, it took more time for reading and understanding. These findings indicate that in both cases, both inferences have been produced, but with minimum activity, that is why they were not perceived innating task.

Teachers should understand the types of inferences that can be generated and propose classifications of these deductions or inferences to be drawn up when evaluating reading. Texts are seldom completely specific. If every concept had to be clearly expressed in a passage, it would not be interesting enough and even it would turn to be longer (Yang, 2021). 
Furthermore Trasmundi et al. (2021), in their research article "Inference Instruction to Support Reading Comprehension for Elementary Students with Learning Disabilities" promote improving reading comprehension using as experimental group learners with learning disabilities (LD) who attend to middle elementary grades. They also offer some suggestions and a five method for educating learners to create text connecting and knowledge stage-based deductions while they are reading. It was concluded that the ability to produce inferences is essential to the learning of high learners.

\section{Methodology}

The present research work is based on a qualitative and quantitative approach. Qualitative approach because the facts will be observed and analyzed. Also, the impact that the application of the Inferring Meaning Strategy has on the improvement of the reading comprehension.

The present investigative work is of exploratory, descriptive and correlational level.

The study covers the level of exploratory because it deals with the characteristics of the research fulfilling the objectives that will be set. The objective of descriptive research is considered fundamental since it consisted in getting to know the predominant situations and attitudes through the exact description of the activities, objects, processes and people in the place where the problem is. In addition, there is correlated research between the variables, so that those under study can be examined. Also, the change from one variable to another and the direct influence between them.

The research project takes place in Tungurahua province, in the city of Ambato, with students from PINE at Universidad Técnica de Ambato. For the development of the study, it was necessary the participation of the 28 students from $5^{\text {th }}$ semester.

For the experimentation to use a pre-test, the first step was to apply a pretest taken from PET (Preliminary English Test) to measure the reading comprehension level of the students. For this part there were considered two from the five parts of the reading section. The second part which consisted of five matching questions and the fourth part which contained five multiple choice questions, giving a total of ten items; and post-test was taken from PET (Preliminary English Test) and the second and fourth part of the reading section were considered. The aim of this was to analyze whether students have improved their reading comprehension level after the application of the Inferring Meaning Strategy.

\section{Results}

Afterwards, a standardized Post-Test taken from the Preliminary English Test (PET) from Cambridge was conducted to the same students. The student's t-test was applied to make 
the statistical analysis. The information obtained contributed to verify the hypothesis and to arrive to the respective conclusions.

Global Representation of Students' Grades

\section{Table 1}

Score Rank

\begin{tabular}{lc}
\hline Bad: & $1-4$ \\
Regular: & $5-6$ \\
Good: & $7-8$ \\
Excellent: & $9-10$ \\
\hline
\end{tabular}

Table 2

Classification of Students according to Results

\begin{tabular}{cccccc}
\hline Results & Bad & Regular & Good & Excellent & Total \\
\hline Pre-Test & 8 & 7 & 7 & 6 & 28 \\
Post-Test & 1 & 6 & 14 & 7 & 28 \\
\hline
\end{tabular}

Figure 2

Classification of Students according to Results



After applying the Pretest, the experimental group was divided into four categories to measure their improvement in a better way. Those categories were: bad, which went from 0 to 4; regular, which rank was from 5 to 6; good, that went from 7 to 8; and excellent, which went from 9 to 10 . When the Pretest was applied it is possible to see that there were 8 students in the first category, which represent the $28.5 \%$; in the second, 
7 that is the $25 \%$; in the third category there were 7 students who also represent the $25 \%$; and finally in the last category there were 6 students equivalent $21.5 \%$.

In this way, it is possible to affirm that the groups that were benefited in a greater way were the bad and the good. Within the "bad" group, which contained at first 8 people, 7 people improved their grades while 1 did not show a great improvement. In other words, there is a decrease from $28.5 \%$ time, the results of the Preto $3.5 \%$ At the same test showed that there were 7 people who belonged to the "good" category, but after taking the Posttest this group doubled its number to 14 . Which means that this group experimented an increase from $25 \%$ to $50 \%$. These results were achievable thanks to the application of the Inferring Meaning Strategy through a series of activities that were carried out during a month.

Student's T-Test with SPSS

Figure 3

Paired Sample Statistics

\begin{tabular}{ll|l|l|r|r} 
& Media & N & \multicolumn{1}{c}{$\begin{array}{c}\text { Desv. } \\
\text { Desviación }\end{array}$} & \multicolumn{1}{c}{$\begin{array}{c}\text { Desv. Error } \\
\text { promedio }\end{array}$} \\
\hline \multirow{2}{*}{ Par1 } & PreTest & 6.14 & 28 & 2.578 & .487 \\
\cline { 2 - 7 } & PostTest & 7.46 & 28 & 1.551 & .293 \\
\hline
\end{tabular}

In this table it is evidenced that the average score that was obtained from the experimental group after taking the Pre-test is 6,14, while the average score after taking the Post-test having passed a month studying and practicing the strategy is 7,45 . Then, to know in the difference among both tests is significant, the student's t-test is applied.

\section{Conclusions}

- It is suggested to apply the Inferring Meaning Strategy when carrying out reading comprehension activities because in that way students will be trained to use their logic, and additionally, students who have bigger problems for understanding a text, will have a guide that will help them und standing explicit information.

- It is important to look for more strategies that could complement this one to achieve better results when teaching reading to students. Moreover, teachers should not forget to focus on this part of skill the reading and to develop the ability of making inferences because it has an impact on language learning. 


\section{References Bibliographical}

Anjarwati, R., Setiawan, S., \& Laksono, K. (2021). Experiential meaning as meaning making choice in article writing: A case study of female and male writers. Heliyon, e06909. Doi: https://doi.org/10.1016/j.heliyon.2021.e06909

Chen, Y. (2021). Comparing incidental vocabulary learning from reading-only and reading-while-listening. $\quad$ System, $102442 . \quad$ Doi: https://doi.org/10.1016/j.system.2020.102442

Cowley, S. (2021). Reading: skilled linguistic action. Language Sciences, 101364. Doi: https://doi.org/10.1016/j.langsci.2021.101364

Demetriou, A., Golino, H., Spanoudis, G., Makris, N., \& Greiff, S. (2021). The future of intelligence: The central meaning-making unit of intelligence in the mind, the brain, and artificial intelligence. Intelligence, 101562. Doi: https://doi.org/10.1016/j.intell.2021.101562

Herazo, J. D. (2021). Mediating spoken meaning-making in genre-based lessons: The role of metalinguistic concepts. System, 102398. Doi: https://doi.org/10.1016/j.system.2020.102398

Johannessen, C., Longcamp, M., Stuart, S., Thibault, P., \& Baber, C. (2021). The look of writing in reading. Graphetic empathy in making and perceiving graphic traces. Language Sciences, 101363. Doi: https://doi.org/10.1016/j.langsci.2021.101363

Odii, B., Huang, Y., des Bouvrie, N., \& Harder, M. (2021). Cycles of meaning-making crystallization in the WeValue InSitu process as clear contributions towards transformative learning. Journal of Cleaner Production, 127024. Doi: https://doi.org/10.1016/j.jclepro.2021.127024

Omland, M. (2021). Technology-aided meaning-making across participation structures: interruptions, interthinking and synthesising. International Journal of Educational Research, 101842. Doi: https://doi.org/10.1016/j.ijer.2021.101842

Rose, D. (2021). Reading metaphor: Symbolizing, connoting and abducting meanings. Linguistics and Education, $100932 . \quad$ Doi: https://doi.org/10.1016/j.linged.2021.100932

Scholander, L., Vikström, S., Mondaca, M., \& Josephsson, S. (2021). Stories under construction: Exploring meaning-making on a geriatric ward. Journal of Aging Studies, 100940. Doi: https://doi.org/10.1016/j.jaging.2021.100940 


\section{DDigital}

Trasmundi, S., Kokkola, L., Schilhab, T., \& Mangen, A. (2021). A distributed perspective on reading: implications for education. Language Sciences, 101367. Doi: https://doi.org/10.1016/j.langsci.2021.101367

Yang, S. (2021). Diagnosing reading problems for low-level Chinese as second language learners. System, 102433. Doi: https://doi.org/10.1016/j.system.2020.102433




El artículo que se publica es de exclusiva responsabilidad de los autores y no necesariamente reflejan el pensamiento de la Revista Conciencia Digital.

\section{\Ciencia}

El artículo queda en propiedad de la revista y, por tanto, su publicación parcial y/o total en otro medio tiene que ser autorizado por el director de la Revista Conciencia Digital.
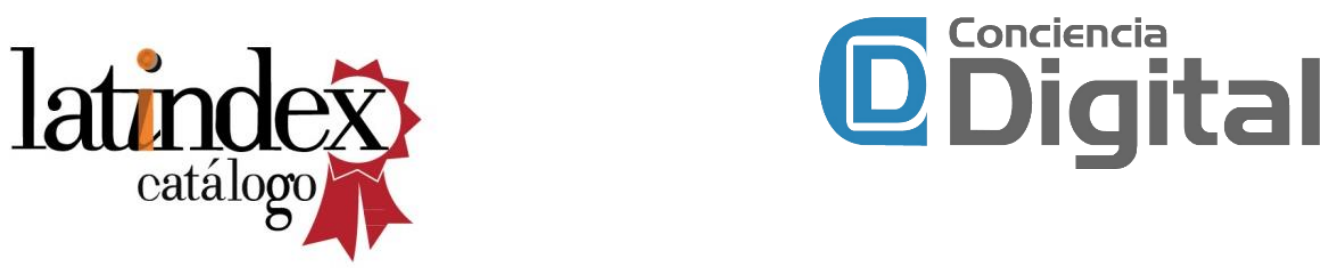

Indexaciones

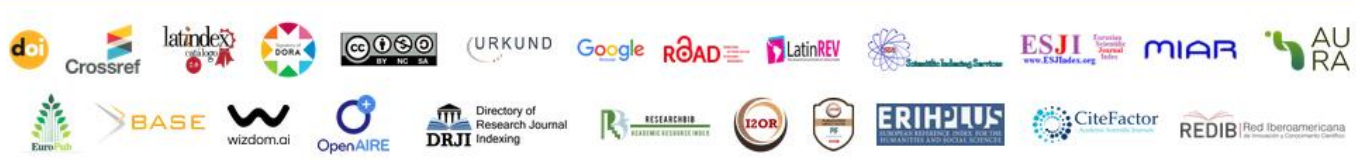

